Resumen y traducción por el autor, Jose F. Nonidez.

Estudios sobre las gonadas de la gallina.

I. Proceses hematopoiéticos en las gonadas de embriones y aves adultas.

En el presente trabajo, primero de una serie dedicada principalmente al estudio del tejido intersticial de las gonadas de gallos con plumaje normal y femenino, pertenecientes a diversas razas, el autor ha estudiado extensamente la contribución de los tejidos hematogénicos en la formación de las gonadas, particularmente en el macho. En el embrión aparece un número considerable de leucocitos granulosos, producidos como resultado de la capacidad hematopoietica del mesenquima. Los estados jóvenes de los leucocitos, representados por células con núcleo redondo y granulaciones acidófilas en el citoplasma, han sido descritos en el adulto por Boring y Pearl como verdaderas células intersticiales. Estas células proceden de hemocitoblastos linfoideos producidos por diferenciación de las células del mesenquima; generalmente desaparecen después que el pollo abandona el huevo, pero también pueden formarse en aves adultas, llegando a constituir en algunos casos, una verdadera metaplasia mieloide del tejido conjuntivo.

Los pequeños linfocitos producidos en las gonadas se transforman en granulocitos de pequeño tamaño y también producen grandes células emigrantes, que, después de acumular grasa en el citoplasma, corresponden en todos sus caracteres a las llamadas células de Leydig y células intersticiales. Su presencia, sin embargo, no es constante. Su origen a expensas de los pequeños linfocitos y su capacidad para acumular grasa indican que son células emigrantes modificadas mas bien que elementos intersticiales. En el macho adulto normal no existe una glándula intersticial bien definida.

Translation by José F. Nonidez

Cornell Medical College, New York 


\title{
STUDIES ON THE GONADS OF THE FOWL
}

\author{
I. HEMATOPOIETIC PROCESSES IN THE GONADS OF EMBRYOS AND \\ MATURE BIRDS ${ }^{1}$ \\ JOSÉ F. NONIDEZ \\ Station for Experimental Evolution, Carnegie Institution of Washington \\ THREE PLATES (TWENTY-NINE. FIGURES)
}

\section{CONTENTS}

Introduction $\ldots \ldots \ldots \ldots \ldots \ldots \ldots \ldots \ldots \ldots \ldots \ldots \ldots \ldots \ldots \ldots \ldots \ldots$

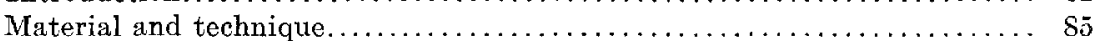

Occurrence of hematopoietic foci in the gonads $\ldots \ldots \ldots \ldots \ldots \ldots \ldots \ldots \ldots$

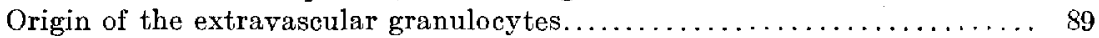

The nature of the so-called interstitial cells.................. 95

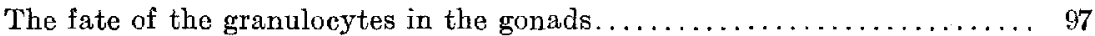

The origin and transformations of the small lymphocytes........... 99

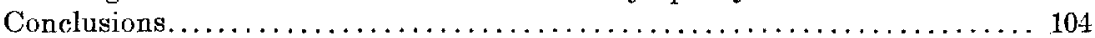

Literature cited $\ldots \ldots \ldots \ldots \ldots \ldots \ldots \ldots \ldots \ldots \ldots \ldots \ldots \ldots \ldots \ldots \ldots$

\section{INTRODUCTION}

The occurrence of a true interstitial gland in the testis of the common fowl has been the subject of much speculation. Strangely enough, in spite of the conspicuous differences in the plumage and other characteristics of the cock when compared with the similar structures of the female, the existence of such a gland has never been established on a sound basis. Some observers maintain that it is absent or feebly developed, hence concluding that the secondary sexual characters must not depend on the presence of specific glandular cells possessing an

1 This paper is based on work done during the winter of 1920 while the author was at the Department of Zoology, Columbia University. I wish to express my deep indebtedness to Prof. T. H. Morgan for the abundant material put at my disposal as well as for encouragement and sympathetic interest throughout the work. Also to Dr. H. D. Goodale, of the Massachusetts Agricultural College, Amherst, through whose kindness I was able to add to my material preserved gonads of embryos and young chicks, as well as several slides showing critical points in the structure of the ovary and testis. 
endocrine function. This view is strengthened by the fact that the plumage, which in the cock is one of the most marked secondary sexual characters, changes but very slightly after castration. The observers who accept the existence of an interstitial endocrine gland have described cells which show granules stained after certain specific treatments, regarding such granules as the secretion of the cells. But in a few instances the mere presence of cells differing morphologically from the ordinary connectivetissue cells has been regarded as a decisive proof of the existence of an interstitial gland.

While the morphological side of the question has been repeatedly attacked in the adult cock, no careful observations have been made on the histogenesis of the testis, especially on the processes of differentiation taking place in the tissues lying between the seminal tubules. As in most organs in the body, the testis is a complex structure made up of different tissues. Aside from the seminal epithelium forming the tubules, there are bloodvessels, lymphadenoid nodules, and connective tissue. The last exhibits a remarkable complexity on account of the presence of wandering cells produced as a result of its hematopoietic capacity which, though more conspicuous during development, does not cease altogether in the adult bird. It is extremely difficult, therefore, to decide on the nature of certain cells present in the gonads unless the histogenesis of these organs has been carefully followed and their connective tissue compared with that found in other regions of the body, both in the embryo and in the adult.

The existence of a distinct interstitial tissue in the ovary of the hen has been reported by Sonnenbrodt, Ganfini, Poll, and Firket. It consists of cells with polygonal outline and round nucleus surrounded by a highly vacuolated cytoplasm (fig. $1, i$ ). These cells usually appear in the form of clusters in the medullary portion of the gonad and around the follicles. The aspect of the tissue strongly points to its epithelial origin. As shown by Firket ('14), such cells arise as a differentiation in the epithelial elements which form the sexual cords of the first proliferation, the germ cells degenerating in the meantime. ${ }^{2}$

${ }^{2}$ A detailed account of the origin of this interstitial tissue in the ovary will be given in another paper dealing with the histogenesis of the gonads. 
Boring and Pearl ('18) have described this tissue in the ovary of normal and hermaphrodite birds, but deny its interstitial nature. They regard the cells forming the clusters as playing an important rôle in the formation of the corpus luteum. Hence the term 'lutear cells' which they have used throughout their papers. The interstitial tissue is represented, according to these observers, by certain granule-laden elements which they have called interstitial cells. These cells are roundish and possess a small, deeply staining nucleus; their cytoplasm is loaded with abundant granules which stain a reddish-purple after Mann's mixture and Mallory's triple stain, taking also the iron hematoxylin. The granule-laden cells may be scattered through the stroma of the ovary, but occur chiefly near the periphery.

The most important point in connection with the existence of these granular interstitial cells is that their presence is not constant and seems to be influenced by the age of the bird. They appear always in the mature female, but they are absent in the ovaries of newly hatched chicks. The reverse condition occurs in the males: the granule-laden cells were not found in the testis of any of the sixty mature birds studied by the observers mentioned above, but occurred in those of four newly hatched chicks, usually forming groups in the connective tissue in which they lie embedded. A comparison of the granule-laden cells of the testis with those present in the ovary showed that aside from certain minor differences in the size of the cell-body and granules, as well as in the structure of the nucleus, both kinds of cells are identical in the male (when present) and the female.

Since the granule-laden cells are not always present in both sexes, Boring and Pearl reached the conclusion that "characteristic, true interstitial cells are neither a necessary nor a constant element in the make up of the testis in the male of the domestic fowl." From this statement they draw the conclusion that "the facts regarding the occurrence and distribution of interstitial cells are such as to make it very difficult to suppose that they have any causal influence upon the secondary sexual characters" ('17, p. 265). 
The interstitial nature of the granule-laden cells described by Boring and Pearl has been recently questioned by Goodale ('19). After a comparative study of the cells present in the gonads with other cells having granular contents, occurring in several organs of the same animal, this observer concludes that both kinds of elements are identical, and therefore, they cannot be regarded as typical interstitial tissue in the ovary and testis. Goodale suggests that the granule-laden cells are cosinophilc leucocytes escaped from the blood-stream.

On account of these conflicting views it seemed advisable to study this question anew, as well as other points regarding the presence of a true interstitial gland in the testis and ovary of the fowl. Much interest has been added to this problem by the results of recent experimental work (Goodale, '13, '16; Pézard, '18; Morgan, '15, '19). The fact that castration in the hen and in hen-feathered males suppresses the female plumage, whose place is taken by cock-feathering, strongly points to the occurrence of a common interstitial tissue in the gonads of both kinds of birds. A further proof of this was found by Boring and Morgan ('18) in the testis of a Sebright bantam cock, in which the so-called lutear cells, typical of the ovary, were also present in the albuginea. Whether the changes caused in the plumage of cocks belonging to this breed, in which all the males are henfeathered, can be accounted for by the removal of a specific tissue homologous to the interstitial tissue of the ovary, cannot be established on a sound basis until a careful study of the histogenesis of the gonads is made. The morphological similarity of the cells regarded as interstitial in both sexes must not be taken as a decisive proof of their functional similarity until their common origin is traced.

However, it was not thought advisable to take up this important subject until the origin and true nature of the granule-laden cells regarded as interstitial by Boring and Pearl could be established on a sound basis. The present paper, therefore, deals exclusively with the origin and distribution of such cells in the ovary and testis of embryos and young chicks. A short description of the same cells in adult birds has also becn included. As 
described in the following pages, the granule-laden cells are but the young stages of the eosinophile leucocytes. Although a description of the processes involved in the formation of the latter is given, the present contribution does not aim to throw any light on the much-discussed question of the origin of blood. It was found necessary to study their relations to blood, in order to prove that the granule-laden cells cannot be regarded as elements having an endocrine function. At the same time, an attempt has been made to determine to what extent the blood-forming elements contribute to the make-up of the complex tissue lying between the seminal tubules and between the ovarian follicles. Once this is done, it will be easier to reach an understanding as to the kind of cells which by their secretion produce the remarkable condition in the plumage of hen-feathered cocks, explaining at the same time the results brought about by castration in the latter and in the normal female.

\section{MATERIAL AND TECINIQUE}

The material used in this work consisted of the testes and ovaries of twenty-six birds belonging to the races Sebright bantams and Rhode Island Reds; the gonads of the latter were preserved for me by Doctor Goodale. Thirteen of the specimens studied were gonads from embryos; the other thirteen belonged to young chicks, four, five, and eight days old. In addition to this material, sections of the gonads of several adult birds were also studied. The source of this material and the methods used in their preservation will be given in subsequent papers.

The testes of embryos 10, 17, 18, 20, and 21 days old, attached to the Wolffian bodies were preserved in Bouin's fluid warmed to $37^{\circ} \mathrm{C}$. The same treatment was used for the ovaries. The gonads of the young chicks were also preserved in Bouin's fluid and a few in Zenker's mixture.

Sections $7 \mu$ thick were stained chiefly with Delafield's hematoxylin and eosin and with iren hematoxylin, light green and orange $\mathrm{G}$ as counterstains. I found unnecessary the use of Mann and Mallory's stains. The same results may be obtained by the 
use of Delafield's hematoxylin and eosin. If the sections be stained previously with a 1 per cent aqueous solution of the latter stain (eosin W.g., Gruebler) and then with a ripe solution of the hematoxylin, most of the eosin will be washed off when dehydrating through the alcohols, leaving only stained in brilliant red the erythrocytes and the granules of the eosinophilic leucocytes, whose distribution can be easily detected even under a low power. The granules appear in deep black after staining with iron hematoxylin, which also reveals minute details in the structure of the cells, such as the sphere, centrioles and earliest stages in the deposition of granules in the cytoplasm.

\section{OCCURRENCE OF HEMATOPOIETIC FOCI IN THE GONADS}

In the mesenchyme of the chick embryo there is a widespread tendency toward the production of blood-elements in certain areas, which thus become hematopoietic foci. The mesenchyme of the gonads being essentially similar to that present in other regions of the body, it is not surprising to find the same phenomena in these organs, leading to an active production of cells which do not differ in any important respect from those found elsewhere in the embryo. In the gonads the products of this hematopoietic capacity of the mesenchyme are either temporary, i.e., appear chiefly in the embryo or may share in the building up of the tissue filling the spaces separating the seminal tubules and ovarian follicles in the mature birds. Among the former, the most conspicuous are the cells belonging to the myeloid group, namely, those elements which contain acidophile granules in their cytoplasm and become eventually eosinophile leucocytes. The permanent elements belong to the lymphatic group and are represented by considerable numbers of small lymphocytes scattered through the stroma of the gonads after their production in lymphatic nodules. In some cases, presumably under the influence of unknown physiological conditions, cells of the myeloid group may also appear in the adult as the result of a myeloid metaplasis of the connective tissue. 
The study of sections of the testis in chick embryos after the ninth day of incubation shows the occurrence of hematopoietic foci in the mesenchyme lying between the sexual cords and young seminal tubules (fig. 7). As stated above, the most conspicuous elements in these hematopoietic foci are the cells possessing granules in their cytoplasm, which stain red after treatment with eosin and deep black in the iron-hematoxylin slides. The size of the granules is variable, even within the same cell (fig. 14). While the morphological characteristics of the cytoplasm and its contents seem to be uniform in these cells, the structure of their nuclei varies a good deal. In this respect, the granuleladen cells both in the testis and ovary fall into two groups: in one may be placed all the cells in which the nucleus is round or oval in outline (myeloblasts, granulocytoblasts, figs. 11 to 14), while in the other the nucleus is polymorphic and often broken into two or three portions (granular leucocytes, granulocytes, figs. $7,15$, and $18, g)$. These two kinds of cells are the extremes of a closely graded series, whose stages, which overlap each other in perfect sequence, may be found lying side by side in the same hematopoietic agglomeration (figs. 7, 15, and 18).

In addition to these elements cells may be found in which no granules occur in the cytoplasm, which is strongly basophile. The nucleus of these cells is round or oval in outline (fig. $2, h^{\prime}$, and figs. 15 and 18), but in the young cells may show a marked tendency toward polymorphism; it contains a faint chromatin network and one or two large karyosomes, which stain a deep black after the iron hematoxylin, but show their compound nature in slides stained with Delafield hematoxylin and eosin. The elements just described obviously correspond to the large lymphocytes or hemocytoblasts (Danchakoff, '16 d) ${ }^{3}$ which according to the observers of the monophyletic school are the common stem-cells for all the elements of the blood. The extra-

${ }^{3}$ In order to avoid the use of synonyms, the nomenclature suggested by Danchakoff (16, d, p. 272) will be used throughout the following pages. In this nomenclature the old term 'Iarge lymphocyte' has been substituted by lymphoid hemocytoblast. Granulocytoblast and granulocy te are equivalent to myeloblast and granular leucocyte (myelocyte), respectively. 
vascular hemocytoblasts become granulocytoblasts after deposition of acidophile granules in their eytoplasm, and transitional stages in this evolution may be found in the same microscopical field (fig. 15). Thus a complete series can be established from an early stage in which no granules have appeared in the cytoplasm to a condition in which the granules are very abundant and the nucleus has lost its round outline to form a crescent-shaped structure which may break into several portions.

After the fifteenth day of incubation small lymphocytes begin to appear in the mesenchyme. They are also formed in the hematopoietic foci and in special lymphopoietic areas which become lymphatic nodules. Besides the myeloblastic and lymphatic elements, there are usually in the clusters formed by both kinds of cells elements endowed with a high phagocytic capacity. The origin of these cells, which closely resemble the hemocytoblasts, is obscure. They play an important rôle in the resorption of the granule-laden cells present in the hematopoietic foci, which are rarely found in the newly hatched and young chicks.

Hematopoietic foci similar in all respects to those mentioned above were also found in the Wolffian bodies (fig. 15), metanephroi, suprarenal glands, developing epididymis, and in the mesenchyme surrounding all these organs. They also occur in the ovary and corresponding organs in the female, showing the same morphological features as those present in the testis. Finally, they were also detected in the loose mesenchyme of the limbs in a ten-day embryo. In all these cases they appear in close proximity to the blood-vessels, in regions occupied by undifferentiated mesenchyme cells.

If we turn to the literature, we can find that hematopoietic foci have been reported in the chick by several observers, especially by V. Danchakoff ('08 a, b; '16 b, c), who has made a careful study of them in her researches on the origin of blood in the hematopoietic organs and mesenchyme of different regions of the body.

Firket ('14) has mentioned the presence of granulc-laden cells in the ovary of embryos from the twelfth to the eighteenth day of incubation. According to this investigator, who recognizes 
a mesenchymal origin for these cells, they arise outside of the ovary, whence they migrate into this organ. While this migration may take place at an early stage in the development of the ovary, their formation within this organ is conspicuous in the embryo of the eighteenth day. Misled by a superficial resemblance between the granulocytes and cells which have phagocyted erythrocytes and leucocytes, Firket regards the former as the 'histiotopen Wanderzellen' of Danchakoff ('08 a). So far as I am aware, the histiotopic wandering cells do not produce any granules in their cytoplasm; the inclusions contained in the latter are the result of the digestion of phagocytized elements, which may be granulocytes, while in the granule-laden cells, so abundant in the gonad, the granules arise by cytoplasmic differentiation.

Leplat (12) has also found hematopoietic foci in the vascular membrane of the eye in the embryo, where they arise, according to this author, as a differentiation of mesenchyme cells. Haff (14) described the origin of granule-laden cells similar to those found in other regions of the body of the embryo in the interlobular spaces of the liver, in chicks from the eleventh day of incubation to the end of the embryonic life; The production of granular leucocytes in the liver reaches its maximum from the fourteenth to the fifteenth day, gradually decreasing after this time.

\section{ORIGIN OF THE EXTRAVASCULAR GRANULOCYTES IN THE GONADS}

The facts mentioned in the preceding pages strongly suggest that the granule-laden cells found in the gonads arise as the result of the myeloid transformation of the primitive blood-cells or hemocytoblasts. Since the origin of the latter from mesenchyme cells has been carefully described by Danchakoff, there is no need of giving a detailed description of the processes involved in their differentiation. The results attained by the writer agree in the main with the descriptions of the observer mentioned above. There are, however, some points which deserve further consideration. The most important of these is the production 
of cells similar to the hemocytoblasts in the endothclium of the blood-vessels. The splitting off of cells from the endothelial lining of the latter is a well-established fact in the embryos of several vertebrates. The proliferation of the endothelium in certain portions of the aorta has been described in the embryos of reptiles (Danchakoff, '08 c; Jordan, '16, '17), birds (Danchakoff, '08 b), and mammals (Maximow, '08; Emmel, '15. '16; Jordan, '16, '17). More recently, McJunkin ('19) has shown that this proliferation also takes place in blood-vessels of certain. organs in the adult mammal.

This proliferation has been generally interpreted as the formation of primitive blood-cells or hemocytoblasts which will eventually become erythroblasts in the blood-stream. MeJunkin, on the other hand, has been able to prove by injecting lampblack into the veins that the endothelium is endowed with an active phagocytic power and that the cells produced by its proliferation become the phagocytic mononuclear elements normally found in the blood.

The formation of large cells by isolation of endothelial cells was taking place in all the embryos studied by the writer, irrespective of their age. However, it was more marked in early embryos than in those ready to hatch.

The endothelium of the veins is made up of flattened cells, while that in the arteries is thicker and contains oval or roundish nuclei, scattered in a continuous layer of cytoplasm, surrounded by elongated mesenchyme cells (fig. $7, b$ ). The cells in both kinds of endothelium are not uniform in size. Here and there cells may be seen which possess an oval, nearly round nucleus of larger size than in the other endothelial elements. Sometimes these large nuclei protrude either into the lumen of the vessel or toward the mesenchyme. During the enlargement of the nucleus the cytoplasm becomes vacuolated. The karyosome increases in size, while the coarse chromatin network gives place to a delicate reticulum. An early stage in this transformation has been represented in figure $3, e^{\prime}$. Figures 4 and 5 show later stages. 
The large endothelial cells thus produced may become more and more isolated from the endothelium and finally migrate toward the surrounding mesenchyme or fall into the lumen of the vessel. It seems likely that their migration into the former may be easier in the case of the veins and small capillaries than in the arteries. The presence of concentrically disposed mesenchyme cells around the latter prevents, or at least hampers, the migration of the young cells toward the mesenchyme. It is true that this mechanical obstacle may be surmounted to some extent on account of the plasticity and amocboid movements of the cells produced by the endothelium, through which these elements may work their way among the fibroblasts and become eventually free.

While there can be little doubt about the formation of large cells in the endothelial lining of the blood-vessels, the ultimate fate of the elements thus produced could not be established in the slides. The occurrence of granulopoietic agglomerations in the vicinity of the vessels might at first lead one to suppose that the endothelium takes an active part in the granulopoietic process. But, at least in the case of the gonads, the formation of granulopoietic foci around the vessels is rather due to the presence of undifferentiated mesenchyme cells in the perivascular tissue than to the existence of an active proliferation in the walls of the vessels. Cases in which large endothelial cells are being produced are so restricted in late stages of development that it is impossible to find transitional stages in this process. The close proximity of the hemocytoblasts to the endothelium does not afford conclusive evidence of their formation in the latter, since such cells could have arisen in the mesenchyme enveloping the blood-vessel. Therefore, it is largely a matter of interpretation whether or not the endothelium contributes to the formation of the clusters of granular leucocytes The occurrence of special phagocytic cells resembling hemocytoblasts in the clusters suggests that the former might have originated in the endothelium. This, however, cannot be accepted without further study.

The formation of granulocytoblasts takes place by the appearance of scattered minute granules around the sphere of the hemocytoblasts, the granules growing meanwhile new granules arise in the cytoplasm. 
Figures 9 and 10 represent two early stages in the deposition of the granular material. In the cell represented in figure 9 the granules are extremely small and occupy the cytoplasmic vacuoles. In the hemocytoblast of figure 10 they have increased in size while new ones are produced. The way in which such granules appear is not well known. It has been suggested that they do not arise directly from the cytoplasm, but that they are derived from the mitochondria (Leplat, '12), a view which is supported by their disposition in rows, connected by strands which stain a little more deeply than the cytoplasm. This disposition is only seen in the very young granules.

When first present the granules show a homogeneous structure, staining deeply after eosin and iron hematoxylin. As growth proceeds they become differentiated into two regions: a peripheral layer slightly irregular, which strongly takes the stain, and a more transparent core. This structure is conspicuous in all the slides, in the stained with eosin as well as in those stained with iron hematoxylin, although in the latter they generally appear. uniformly stained in deep black, when decolorization was not pushed too far. Occasionally the granules may change into rods, which are characteristic of the eosinophile leucocytes in the blood-stream (Danchakoff, '08 a, b; Schmeisser, '15; Kaupp, '18).

With the deposition of granular material there appear several changes in the morphology of the nucleus, which may become irregular in outline from a very early stage or preserve its round contour. The chromatin network stands out more clearly, whereas the karyosomes tend to decrease in bulk, the plasmosomes being almost entirely deprived of the layer of chromatin granules in which they lie embedded. The plasmosomes themselves shrink, eventually disappearing at later stages.

The cells with round nucleus and granular cytoplasm or granulocytoblasts may increase in numbers by mitosis, during which the granules are irregularly distributed among both daughter cells, which preserve the same characteristics as the mother cell or undergo the process which changes the granulocytoblasts into granular leucocytes. 
The granulocytoblasts represent a transitory stage in the evolution of the extravascular hemoblasts and soon change into granulocytes or special granular leucocytes. This transformation could be followed step by step in the clusters present in the mesenchyme. The closely graded scries of stages which may be obtained from a single cluster brings forth conclusive evidence on this point (figs. 7 and 15).

The first manifestation in the production of a granulocyte is the tendency of the nucleus to break into two or more pieces by nuclear constriction followed by the total separation of the portions thus detached. The nucleus stretches out in the direction of one of its diameters adopting a more or less marked crescent shape, whose concavity encloses the sphere and the centrioles (fig. 16 and 17). The two halves thus constricted off may persist united with each other by means of a connecting strand or separate altogether. This process is accompanied with a deep transformation in the nuclear structure. The karyosome, which is already diminished in size in the granulocytoblasts, shrinks still more in these stages, while the chromatin network develops irregular knots which change into dense masses located in the periphery of the nucleus. The latter shrinks as a whole, becoming darker (figs. 2, 5, and $7, g$ ). Transitional stages between the nucleus with a network and the new condition are even found within the same cell. Sometimes a nuclear portion has already been detached from the main portion of the nucleus, and it shows dense chromatin blocks while the network may still be recognized in the larger nuclear mass.

A comparison of the nuclei of the granulocytes with those in the intravascular leucocytes reveals a striking similarity. The only difference between the two kinds of cells is the condition of the sphere, which in the leucocytes of the blood-stream persists well developed enclosing the centrioles, while in the granulocytes of the mesenchyme it has almost entirely disappeared, leaving remnants in the form of granules in the vicinity of the nucleus. On account of this transformation, the granulocytes have lost their capacity for division and become cells doomed to disappear engulfed by the cytoplasm of phagocytic elements. The presence 
of acidophile rods in the intravascular leucocytes is by no means a distinctive feature of these cells, for such rods may also develop in extravascular granulocytes, although this is not so common.

The transformation of a hemocytoblast into a polymorphonuclear cell may take place very early, even before the granules begin to arise in the cytoplasm. The granules develop later and attain a rapid increase in size (fig. $5, g$ ). On the other hand, nuclear constriction and deposition of granules may occur simultaneously, without a definite stage of granuloblast with round nucleus. The final result is the same in every case, namely, the production of a polymorphonuclear granulocyte.

Although the hematopoietic capacity of the connective tissue has considerably decreased in the gonads of mature birds, it is possible to find isolated granulopoietic foci in both the testis and the ovary. In the latter the production of granulocytes is a general feature, though it varies a good deal in its intensity. Small clusters of granule-laden leucocytes could be detected in some parts of the testis in a Campine cock over one year old. The occurrence of granular leucocytes in the adult testis has also been reported by Goodale ('19) in an old hen-feathered silverspangled Hamburg. I have seen one of the slides of this bird, and there can be no doubt as to the correctness of the interpretation of such cells by the observer just mentioned. In most of the cocks, however, scores of sections examined did not show a single extravascular granulocyte.

The granulocytes in the young and adult ovary occur both in the stroma and in the theca externa of the follicles, usually grouped in small granulopoietic foci. In some cases, however, the production of granular leucocytes reaches such an intensity as to constitute a true metaplasis of the connective tissue. One of these cases has been represented in figure 18, drawn from a slide of the ovary of a pullet, kindly sent to me by Dr. H. D. Goodale. The inspection of this figure shows that almost all the stages represented in the hematopoietic foci of the embryo (figs. 7 and 15) are also present in the granulopoietic agglomerations of the young ovary. This myeloid metaplasis is taking place everywhere in the organ, in the stroma as well as in the theca 
externa of the follicles. It is not so conspicuous in the so-called theca interna.

That the granulocytes thus produced recognize a mesenchymal origin and are not derived from the blood is obvious on account of the early stages in the transformation of the mesenchyme cells into hemocytoblasts. Furthermorc, no granulocytes could be detected within the blood-vessels, even in the case of the small capillaries.

The occurrence of myeloid metaplasis in the mature bird points to the existence of a stock of undifferentiated mesenchyme cells, endowed with multiple potentialities. Under the influence of unknown physiological stimuli, such unmodified cells may proliferate, giving rise to hemocytoblasts which undergo the same evolution as those present in the mesenchyme of the embryo. As will be described in the following pages, the myeloid transformation also affects the small lymphocytes which produce acidophile granules in their cytoplasm and eventually change into a smaller type of granulocytes. Danchakoff $(' 16 b, c)$ has described a syncytium of mesenchyme cells in the nodules of lymphadenoid tissue, where considerable numbers of small lymphocytes are produced. Elements with all the characteristics of undifferentiated mesenchyme cells were found by the writer both in the testis and ovary of the adult bird. These cells persist in the gonads during a long time, perhaps throughout the life of the individual. They occur in the intertubular spaces and also in the stroma of the ovary, and represent portions of the embryonic mesenchyme which have failed to change into fibroblasts. The latter appear chiefly around the seminal tubules and ovarian follicles.

THE NATURE OF THE SO-CALLED INTERSTITIAL CELLS (BORING AND PEARL)

The facts described in the preceding pages establish on a sound basis the homology of the hematopoietic foci found in the mesenchyme of the gonads and those present elsewhere in the general mesenchyme of the embryo. Special emphasis has been laid on the transformation of the granulocytoblasts into granular leuco- 
cytes because the former agree in all respects with the cells called 'interstitial' by Boring and Pearl. A careful comparison of the descriptions and figures published by these observers and the granulocytoblasts present in the gonads has proved beyond any doubt the identity of both kinds of elements.

Therefore, the close similarity of the 'interstitial' cells in the two sexes of the fowl is not surprising, since they originate from the same stem cells by entirely similar processes. Their presence in the testis of newly hatched chicks can be easily explained on account of the persistence of the granulocytoblasts produced by the mesenchyme during the late stages of development. The same can be applied to the case of the female.

While most of the granulocytes have disappeared at the time of hatching, this does not mean that the hematopoietic capacity of the mesenchyme has entirely ceased. It is true that in some cases it has considerably decreased, and even no signs of it can be detected. But the occurrence in both sexes of myeloid metaplasis shows that under certain conditions the formation of granular leucocytes may start again showing the same features of the granulopoiesis in the embryo. This accounts for the presence of granulocytoblasts in the mature gonads. Since these elements are the only kind of granule-laden cells present in the ovary and testis and are connected with typical eosinophile granulocytes by a closely graded series of stages, it is safe to assume that they do not constitute a tissue endowed with a specific endocrine function. A further proof of this is found in the fact that the granule-laden cells are not restricted to the gonads, but occur elsewhere in the general mesenchyme. At least, it cannot be proved that the cells present in the gonads differ from those in other organs in any constant and fundamental characteristic.

The interstitial nature of the granule-laden cells described by Boring and Pearl, therefore, is not warranted by any fact other than a superficial resemblance with elements regarded as glandular in the testis of mammals. 
THE FATE OF THE GRANULOCYTES IN THE GONADS

As stated above, the granulocytes so abundant in the gonads of the embryo begin to disappear after hatching until they are no longer found as important elements in the make-up of those organs. The way in which this disappearance takes place has some importance from the standpoint of hematology, for if it can be proved that most of the granulocytoblasts enter the blood we must regard the gonads of the embryo as transitory hematopoietic organs, a function which has not been attributed to them. A careful study of this problem showed that the vast majority of the mature granulocytes either undergo disintegration or are phagocytized by special elements and by the endothelial lining of the blood-vessels.

That the granulocytes enter the blood-stream is very difficult to prove in the slides. Stages showing their migration through the endothelium are extremely scarce and almost in every case open to criticism. A careful study of the blood-vessels in the vicinity of hematopoietic foci failed to show the occurrence of granulocytes within their lumina in numbers large enough to warrant the interpretation mentioned above. It might be argued that this feature is due to the blood-current which sweeps away the granulocytes as they enter the blood-vessels; but even taking this into account, it is reasonable to expect that some of those cells would be present in the smallest capillaries, where the blood current is slower.

Degeneration of granulocytes and their digestion by phagocytic elements are common in the hematopoietic foci. The degenerated granulocytes are represented by elements somewhat smaller than the normal cells of the same kind, containing a deeply stained, much shrunken nucleus in which no definite structure can be made out. The cytoplasmic granules are clumped and their outlines are often difficult to detect (fig. 18, g). The cell finally breaks up, setting free the granules, which may persist for a long time scattered through the hematopoietic agglomeration. Extrusion of granules by either the granulocytoblasts or granulocytes was never observed in the slides as a normal process. 
Normal or degenerated, the granule-laden leucocytes and their young stages may be preyed upon by special phagocytic cells (figs. 19 to 21), which the writer would identify with the hemocytoblasts were it not for the fact that they show constant specific differences. The phagocytic cells first appear in the hematopoietic foci as elements no larger than dwarf hemocytoblasts, from which they differ chiefly in the absence of a conspicuous sphere and the nature of their cytoplasm, which is not basophilic and shows a faint network (fig. 19). These cells grow until they attain a considerable size, which may be still increased by the presence of phagocytized cells in their cytoplasm. The homology of the phagocytic cells with the histiotopic wandering cells is also difficult to establish. According to Danchakoff (' $08 \mathrm{~b}$ ) the latter show a marked tendency toward polymorphism and are endowed with phagocytic properties. They arise as a transformation in the undifferentiated mesenchyme cells and also as the result of a peculiar evolution of the small lymphocytes. Since the origin of the phagocytic cells present in the gonads could not be traced, it seems advisable to speak of them as the "phagocytic cells' until further investigations show their true nature. Their origin from the endothelial lining of the blood-vessels has been suggested elsewhere (p. 91).

Figures 20 and 21 represent two phagocytic cells which have engulfed granulocytoblasts and granulocytes. The cell drawn in figure 20 is binucleate. Phagocytosis of erythrocytes by hemocytoblasts has been reported in the spleen by Danchakoff (' $16 \mathrm{~d}$, fig. 19) and, although the figure given by this observer and figures 20 and 21 agree in many respects, yet the homology of both kinds of cells is not backed by conclusive evidence on their common origin.

The phagocytic capacity of the endothelium was very conspicuous in sections of a piece of testis undergoing regeneration. No granulocytes were present in this slide. Their place had been taken by large numbers of small lymphocytes (fig. $22, l$ ) which are produced in the mesenchyme as the result of a lymphoid metaplasis, which will be described later. The small lymphocytes thus produced migrate toward the blood-vessels and even- 
tually succeed in penetrating into the veins but many of them are phagocyted and digested by the endothelial cells. The phagocytosis of granulocytes by the endothelium is not so common and may be due to their lessened wandering capacity.

In degenerating blood-vessels the contents are also phagocyted by the endothelium, whose cells increase considerably in size after engulfing a considerable number of erythroblasts and other cells. It is possible that also the ordinary mesenchyme cells may contribute to the resorption of the granulocytes, but no clear cases of this process could be found in the slides.

\section{THE ORIGIN AND TRANSFORMATIONS OF THE SMALL LYMPHOCYTES}

In contrast with the accidental occurrence of stages in the formation of the granulocytes, the small lymphocytes are a normal constituent of the gonads, both in the late embryos and in mature birds. They have been regarded as connective-tissue cells by Miss Boring ('12). According to this investigator, the connective tissue in the adult bird is made up of cells which differ in the structure of their nuclei; some of the latter are round and stain deeply, while others are oval or elliptical in outline. Miss Boring regards this difference in the shape of the nuclei as due to mechanical pressure conditions and states that "it is possible to form a complete series of nuclei ranging gradually from the typical elliptical connective tissue nuclei to the round undifferentiated nuclei"' ('12, p. 150). Cells similar to the elements with round nuclei described by Boring were abundant in the gonads studied by the writer. While some of them are undifferentiated mesenchyme cells, there can be little doubt that the cells with deeply stained nucleus do not belong to the connective tissue. Their morphological characteristics and origin in the lymiphatic nodules clearly show that they are small lymphocytes.

The small lymphocytes begin to appear in the gonads and adjoining organs after the fifteenth day of the incubation, gradually increasing in numbers until they form one of the normal constituents in the adult gonads. They show their typical structure, 
namely, a small nucleus surrounded by a thin layer of cytoplasm; the nucleus contains chromatin blocks located in its periphery and lacks a plasmosome (fig. 22, $l$ ). The small lymphocytes are formed in the mesenchyme surrounding the blood-vessels and also in certain places which later become lymphatic nodules, arising from cells which agree in their characteristics with the elements called dwarf hemocytoblasts by Danchakoff, who described these cells in the spleen of the chick ('16,d). The dwarf hemocytoblasts either differentiate into large hemocytoblasts or into small lymphocytes. Although in the spleen both kinds of elements' are at first separated, in the gonads and adjoining organs, they appear side by side in the same lymphogranulopoietic focus (fig. $15, t^{\prime}, l$ ).

The formation of small lymphocytes in the mature gonads may be very active under certain physiological conditions, leading in some cases to a lymphoid metaplasis of the connective tissue. One of these cases has been represented in figure 22, drawn from a section of the regenerating testis in an adult Campine cock. Large areas of the intertubular tissue are occupied by an enormous number of small lymphocytes and small-sized hemocytoblasts. Transitional stages are also found in large numbers. Some of the mesenchyme cells have become large hemocy toblasts, but the latter do not develop acidophile granules in their cytoplasm and exhibit a marked tendency to divide by amitosis. Once produced, the small lymphocytes migrate toward the bloodvessels and eventually penetrate into their lumina to be carried by the blood to other regions of the body. They appear in large numbers within the veins, but could not be detected in the arteries. Their migration into the latter seems to be preyented by the thickness of the endothelium in these vessels and also by the fibroblasts surrounding the endothelium.

The most important point in connection with the presence of small lymphocytes in the gonads is their transformation into several types of cells which sometimes occur in the connective tissue separating the seminal tubules in mature birds. While some of these cells can be easily identified as modified lymphatic elements, there are others, however, which closely resemble the 
interstitial cells of mammals and have been regarded as such in the testis of the mature cock (Mazzetti, '11; Reeves, '15).4 Figures 27 and 28 represent two of these cells drawn from sections of the testis in a mature hen-feathered Campine cock. The cytoplasm is acidophile, finely granular in structure, and shows irregular vacuoles. In sections stained for fat droplets of the latter substance can be sometimes detected in the cytoplasm. The nucleus is round and shows a coarse chromatin network in which one or two nucleoli are embedded. The position of the nucleus within the cell-body is variable, but quite often it is excentric. The irregular outline of the cell coupled with the usual excentric position of the nucleus indicates that in all probability such elements may wander through the connective tissue. The polymorphism of the cell-body is very marked in extreme cases, and the cell may possess short branches or blunt pseudopods; otherwise they tend to be polygonal or round in outline. This condition seems to be related to the presence of large vacuoles in the cytoplasm.

The cells just described are not a constant element in the make-up of the testis of the mature bird. While those represented in figures 27 and 28 were found in an adult hen-feathered Campine, inspection of the testis in another hen-feathered cock of the same breed, castrated when it was over four months old, failed to show the occurrence of wandering cells. That such cells are also found in cock-feathered birds is proved by their presence in the testis of an adult Rhode Island Red cock and other cock-feathered birds of the same breed. When present, the cells under consideration appear usually scattercd in the intertubular spaces, but in some places they may be grouped in diffuse agglomerations. When they are very abundant they may even give rise to true

\footnotetext{
${ }^{4}$ Besides these authors, several observers have also regarded these elements as interstitial cells. Reeves has represented in his paper two kinds of cells which have no genetic relationship. Those represented in his figure 1, drawn from a cock eighteen months old, correspond to the wandering cells derived from the small lymphocytes. The cells represented in his figures 2 and 3 drawn froni slides of a much younger bird arise as a transformation which takes place in the cells of the sexual cords during a late stage in development. 'The origin of such cells will be deseribed in another paper.
} 
clusters of cells. Their presence in the ovary is still an open question, which the writer did not study owing to the lack of suitable material.

In young birds the wandering cells seem to be more abundant, but this is probably due to the amount of tissue lying between the seminal tubules. When the latter increase in size with the appearance of spermatogenesis the intertubular connective tissue is reduced to thin tracts and the wandering cells are widely scattered throughout the organ to be found only in places where the connective tissue is most developed.

The similarity of the cells just described with the elements reported in mammals and birds under the name of Leydig cells and interstitial cells is obvious. The increase in numbers in these so-called interstitial cells during the breeding season has been claimed by some observers in certain mammals. In birds, however, the most recent studies (Pózard, '18; Stieve, '19) show that there is not such an increase. On the contrary, Pézard's researches in the pheasant point to a marked diminution of the interstitial cells during the stage of sexual activity; they increase in numbers during the winter season, when the testis appears in a quiescent condition. Stieve claims that the amount of interstitial cells in Colaeus monedula is the same whether the bird is killed during the winter or during the breeding season.

The absence of wandering cells in birds with fully developed sexual characters and the considerable variation in their numbers in different cocks make it very hard to believe that such cells are concerned with the secretion of a specific hormone influencing the secondary sexual characters. The origin of such cells in adult cocks further shows that in all probability they are wandering cells similar to those described in the general connective tissue. ${ }^{5}$ They arise from small lymphocytes migrated from the

${ }^{5}$ The connective tissue of the fowl has been described by Solucha (quoted by Danchakoff, '16 c). Since the paper is written in Russian, I have not been able to read his description of the wandering cells. The transformation of the small lymphocytes into histiotopic wandering cells has been mentioncd by Danchakoff in several of her papers. The polymorphism of the cells found in the gonads suggests that they may belong to the same kind of elements, although they are probably slightly modified on account of environmental conditions which are not found elsewhere in the connective tissue. 
lymphatic nodules or brought into the testis by the blood-stream, and the stages in their formation could be followed in some of the agglomerations of wandering cells present in the connective tissue, side by side with cells which had completed their evolution. The cytoplasm of the small lymphocytes enlarges and at the same time acquires small vacuoles, preserving its basophile nature for some time (fig. 23). The nucleus also enlarges and the chromatin blocks so characteristic of the small lymphocyte become first ragged in outline (fig. 24), then appear diffuse, and finally merge into a network (figs. 25 and 26). As the growth of the small lymphocytes takes place very slowly, transitional stages are abundant in the intertubular connective. Eventually the wandering cells become fat laden and lose their wandering capacity. The fate of such cells could not be determined in the slides. It seems likely that the fat stored in the cytoplasm may be used by the actively growing cells within the seminal tubules or even transformed into a specific hormone which exerts its influence on those secondary sexual characters affected by castration in the cock-feathered bird (Loisel, Pézard).

The fact which I wish to emphasize here is that the so-called interstitial cells are modified small lymphocytes and that wandering cells recognized as of the same origin have been described in the general connective tissue. Their relative abundance in the testis may be accounted for by the intense proliferation which is taking place within the seminal tubules, which implies an increased metabolism in their cellular contents. Since no adipose tissue is found in the testis, it is possible that cells which would not store fat in other organs have acquired this function in the gonad as the result of definite environmental conditions, and this would explain the continuous formation of fat-laden wandering cells during the period of heightened sexual activity. The absence of such cells in some birds shows that in the event of having a well-defined endocrine function they may determine the secondary sexual characters in the young cock, but are not necessary for the maintenance of those characters. On the strength of these findings, it is safe to assume that the adult cock-feathered male lacks a specific interstitial tissue. 
The small lymphocytes may also differentiate into cells containing acidophile granules. The latter first appear as very minute bodies scattered in the thin layer of cytoplasm enveloping the nucleus (fig. 29). 'This second type of granule-laden cells may be readily recognized, at least during the early stages, on account of the structure of their nuclei and smaller size. As in the case of the hemocytoblasts, the fate of the small lymphocytes is sealed when the granules appear in their cytoplasm. These granular cells eventually change into a smaller type of granulocytes after constriction of their nuclei, losing the sphere and centrioles along with their capacity for mitotic division. The transformation of the small lymphocytes into granular elements was very conspicuous in the myeloid metaplasis found in the ovary of the pullet already referred to in the preceding pages.

Other lines of differentiation in the small lymphocytes have been described by several observers, but they are not apparent in the connective tissue of the gonads, although they may possibly occur in these organs. Therefore, there is no need of mentioning them here.

\section{CONCLUSIONS}

1. In the gonads of the fowl, both in the embryo and mature bird, there is a widespread tendency toward the formation of blood-cells which usually appear grouped in lymphogranulopoietic foci. The elements of the myeloid group are represented by cells loaded with acidophile granules. The cells of the lymphatic group appear in the form of small lymphocytes which are a normal constituent of the tissue filling the spaces separating the seminal tubules and ovarian follicles. Similar granulolymphopoietic foci also occur in other organs and in the general mesenchyme.

2. The granule-laden cells could be traced to elements with basophilic eytoplasm deprived of granules. Such cells are the hemocytoblasts (Danchakoff) or large lymphocytes. They arise as a differentiation in the mesenchyme cells. Their origin from the endothelium of the blood-vessels could not be established in the gonads. 
3. The hemocytoblasts become granulocytoblasts (= myeloblasts) after deposition of acidophile granules in their cytoplasm. While in this stage they preserve the round shape in their nuclei and may increase in numbers by mitosis.

4. The granulocytoblasts eventually become eosinophile leucocytes after constriction of their nuclei, which usually break into two or more portions. The eosinophile leucocytes or granulocytes (Danchakoff) thus formed are elements doomed to disappear engulfed by the cytoplasm of special phagocytic cells and are also phagocytized by the endothelium. They may degenerate in situ, setting free the granules contained in their cytoplasm.

5 . The small lymphocytes, produced in the mesenchyme and lymphatic nodules, are cells endowed with several cell potentialities. Besides becoming granular leucocytes of smaller size, they give rise to large wandering cells which agree in their characteristics with cells hitherto regarded as interstitial. Such cells may store fat in their cytoplasm, thus losing their wandering properties. Since they may be entirely absent in some testes it does not seem probable that they possess an endocrine function. Though they may perhaps have some bearing on the appearance of the secondary sexual characters in the young bird; they are not necessary for the maintenance of such characters in the adult.

6. The granule-laden interstitial cells described in the ovary and testis by Boring and Pearl are granulocytoblasts (= myeloblasts) produced as the result of the hematopoietic capacity of the connective tissue. The production of such cells may be very active under certain unknown physiological conditions, leading to a myeloid metaplasis of the connective tissue.

7. The mature cock-feathered male lacks a specific interstitial tissue influencing the secondary sexual characters. 


\section{LITERATURE CITED}

Boring, A. M. 1912 The interstitial cells and the supposed internal secretion of the ehicken testis. Biol. Bull., v. 23.

Boring, A. M., AND Morgan, T. H. 1918 Lutear cells and hen-feathering. Journ. Gen. Physiol., v. 1.

Boring, A. M., and Pearl, R. 1917 Sex studies. IX. Interstitial cells in the reproductive organs of the chicken. Anat. Rec., v. 13.

1918 Sex studies. XI. Hermaphrodite birds. Jour. Exp. Zoöl., v. 25.

DanchakofF, V. 1908 a Entwickelung des Blutes bei den Vögeln. Anat. Hefte, Bd. 37.

$1908 \mathrm{~b}$ Untersuchungen über die. Entwickelung von Blut und Bindegewebe bei den Vögeln. Das lockere Bindegewebe des Hühnchens im fetalen Leben. Arch. mikr. Anat., Bd. 73.

1916 a Ueber die Entwickelung des Blutes in den Blutbildungsorganen (Area vasculosa, Dottersackanbänge, Knochenmark, Thymus, Milz und lockeres Bindegewebe) bei Tropidonotus natrix. Ibidem, Bd. 87. $1916 \mathrm{~b}$ Origin of the blood-cells, development of the hematopoietic organs and regeneration of the blood-cells from the standpoint of the monophyletic school. Anat. Rec,, y. 10.

$1916 \mathrm{c}$ The wandering cells in the loose connective tissue of the bird and their origin. Ibidem., v. 10.

$1916 \mathrm{~d}$ Equivalence of different hematopoietic anlages (by method of stimulation of their stem cells). I. Spleen. Am. Jour. Anat, v. 20. 1918 e Equivalence of different hematopoietic anlages, etc. II. Grafts of adult spleen on the allantois and response of the allantoic tissue. Ibidem., v. 24.

Emmes, V. E. 1915 The cell-clusters in the dorsal aorta of the pig embryo. Anat. Rec., v. 9.

1916 The cell-clusters in the dorsal aorta of mammalian embryos. Am. Jour. Anat., v. 19.

Firket, J. 1914 Recherches sur l'organogenese des glandes sexuelles chez les oiseaux. Arch. de Biol., T. 29.

Goodale, H. D. 1913 Castration in relation to the secondary sexual characters of Brown Leghorns. Amer. Nat., v. 47.

1916 A feminized cockercl. Jour. Exp. Zoöl., v. 20.

1916 Further developments in ovariotomized fowl. Biol. Bull., v. 30.

1916 Gonodectomy in relation to the secondary scx-characters of some domestic birds. Carnegie Inst. Wash., publ. 243.

1919 Interstitial cells in the gonads of the domestic fowl. Anat. Rec., v. 16.

HaFF, R. 1914 Bindegewebs- und Blutbildungsprozesse in der embryonalen Leber des Huhns. Arch. mikr. Anat., Bd. 84.

Jondan, H. E. 1916 Evidence of hemogenic capacity of endothelium. Anat. Rec., v. 10.

KaUPP, B. F. 1918 The anatomy of the domestic fowl. Philadelphia.

Leplat, G. 1912 Recherches sur le développement de la structure de la membrane vaseulaire de l'ocil des oiseaux. Areh. de Binl., T. 27. 
McJuxkis, F. A. 1919 The origin of the phagocytic mononuclear cells of the peripheral blood. Am. Jour. Anat., v. 25.

Maximow, A. 1908 Untersuchungen über Blut und Bindegewebe. I. Die frühesten Entwickelungsstadien der Blut- und Bindegewebszellen beim Säugetiercmbryo, bis zum Anfang der Blutbildung in der Leber. Arch. mikr. Anat., Bd. 73.

Mazzetri, L. 1911 I caratteri sessuali secondari c le cellule interstiziali del testicolo. Anat. Anz, Bd. 38.

Morgan, T. H. 1915 Demonstration of the appearance after castration of cock-feathering in a hen-feathered cockerel. Proc. Soc. Exp. Biol. and Med, v, 13.

1919 The genetic and the operative evidence rolating to secondary sexual characters. Carnegie Inst. Wash., Pub. 285.

Pearl, R., and Boring, A. M. 1918 Sex studies. X. The corpus luteum in the ovary of the domestic fowl. Am. Jour. Anat., v. 23.

Pízaro, A. 1918 Le conditionnement physiologique des caractères sexucls secondaires chez les oiseaux. Thèses Facul. Soiences, Paris.

ReEvas, T. B. 1915 On the presence of interstitial cells in the chicken's testis. Anat. Rec, v. 9.

Schmeisser, H. C. 1915 Tenkaemia of the fowl spontaneous and experimental. Johns Hopkins Hosp. Rep.

Stieve, H. 1919 Das Verhältniss der Zwischenzellen zum generativen Anteil im Hoden der Dohle (Colaeus monedula). Arch. f. Lntw.-Mech., Bd. 45. 


\section{EXPLANATION OF PLATES}

All figures were drawn with the camera lucida at table level with Zeiss aposhr. imm. $1.5 \mathrm{~mm}$. objective. For figures $1,2,7,15,18$, and 22 , Spencer ocular 10 was used; the other figures were drawn with Zeiss comp. ocul. 12. Unless otherwise stated, all figures were drawn from slides preserved with Bouin's fluid and stained with iron hematoxylin. The plates were reduced onc-third in reproduction.

ABBREYIATIONS

$b$, blood-vessel

$d$, dwarf hemocytoblast

$e$, endothelium

$g$, granulocyte

$h$, hemocy toblast $l$, small lymphocyte

$m$, granulocytoblast

$s$, cells of the sexual cords

$t$, transitional stages betweon the granulocytoblasts and granulocytes

\section{PLATE 1}

EXPLANATION OF FIGURES

1 A portion of the medullary zone of the ovary in a Sebright embryo of the eighteenth day of incubation. $i$, interstitial cells (lutear cells of Boring and Pearl) almost entirely surrounding a germ cell; o, germ cells. Delaf. hematox. cosin.

2 Loose mesenchyme separating the testis from the Wolffian body in the cmbryo of the tenth day of incubation. $h^{\prime}$, extravascular hemocytoblasts.

3 Endothelium of a capillary in the tenth-day embryo. One of the endothelial cells, $e^{\prime}$, begins to increase in size to be transformed into a large cell. $r$, erythrocyte.

4 Two large endothelial eells almost entirely differentiated from the endothelium of an artery.

5 Large cndothelial cell about to be detached from the endothelium of a capillary. Figures 3,4 , and 5 were drawn from slides of the tenth-day embryo. 


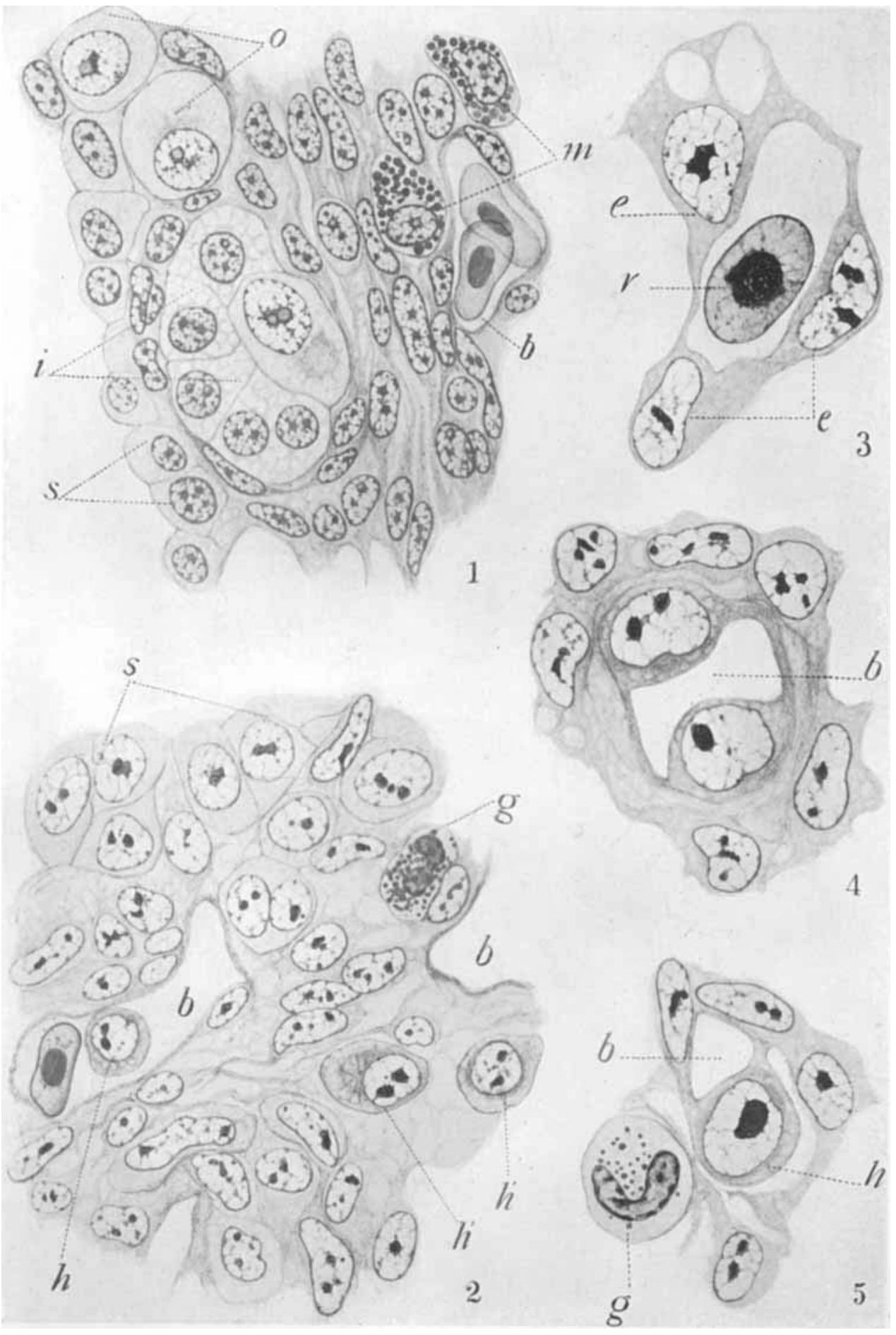




\section{PLATE 2}

\section{EXPLANATION OF FIGURES}

6 Lymphoid hemocytoblast arising in the mesenchyme separating the testis irom the Wolffian body in the tenth-day embryo.

7 Granulopoietic focus in the loose mesenchyme of the testis of the embryo of the eighteenth day of incubation. Several stages in the formation of granulocytes occur around two arteries. In one of the latter a large endothelial cell is arising. $f$, histiotopio wandering cells; $p$, pigmentary cell; $l$, transitional stages between the granulocytoblast, $m$, and the granulocytes, $g$. Delaf. hem. eos.

8 Fxtravascular hemocyloblast prior to the deposition of acidophile granules. Same stain as precoding.

9 to 12 Several stages in the deposition of acidophile granules in the cytoplasm of hemocytoblasts.

13 Three young hemocytoblasts in contact with a blood-vessel. Mesenchyme separating the Wolffian body from the dorsal body wall.

14 Large granulocytoblasts with swollen acidophile granules. Degenerating ovary of the eighteenth-day cmbryo. Delaf. hem. eos.

15 Hematopoietic foeus in the ventral surface of the Wolffian body. Embryo of the eighteenth day of incubation. $l^{\prime}$, dwarf homocytoblast changing into a small lymphoeyte. Delaf. hem. cos. 
THE GONADS OF THE FOWL

PLATE 2 JOSE F. NONIDEZ
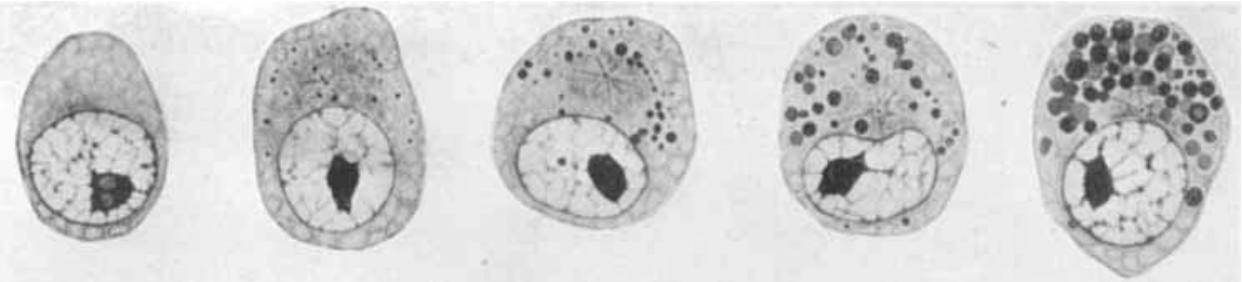

8

9

10

11

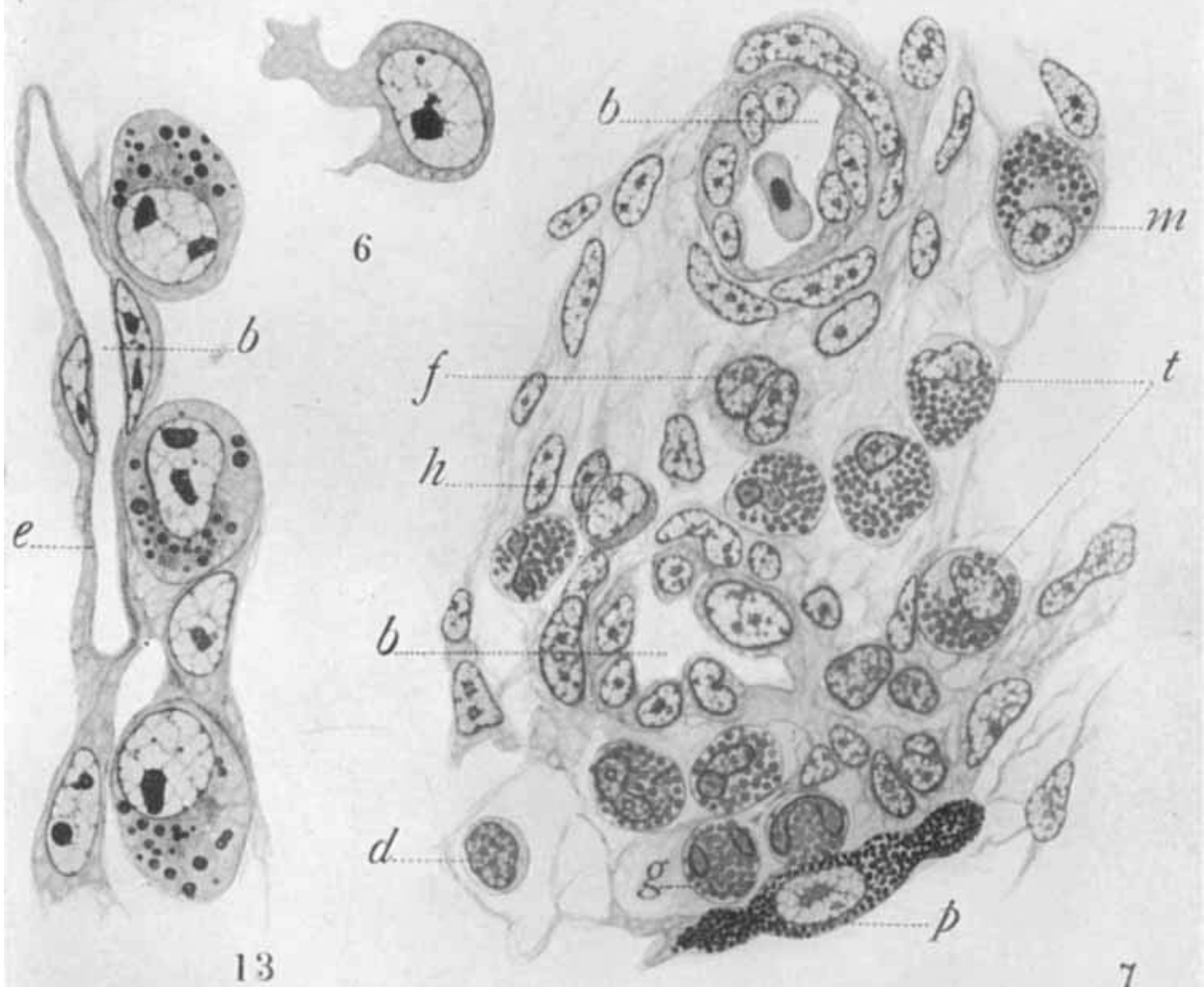

13
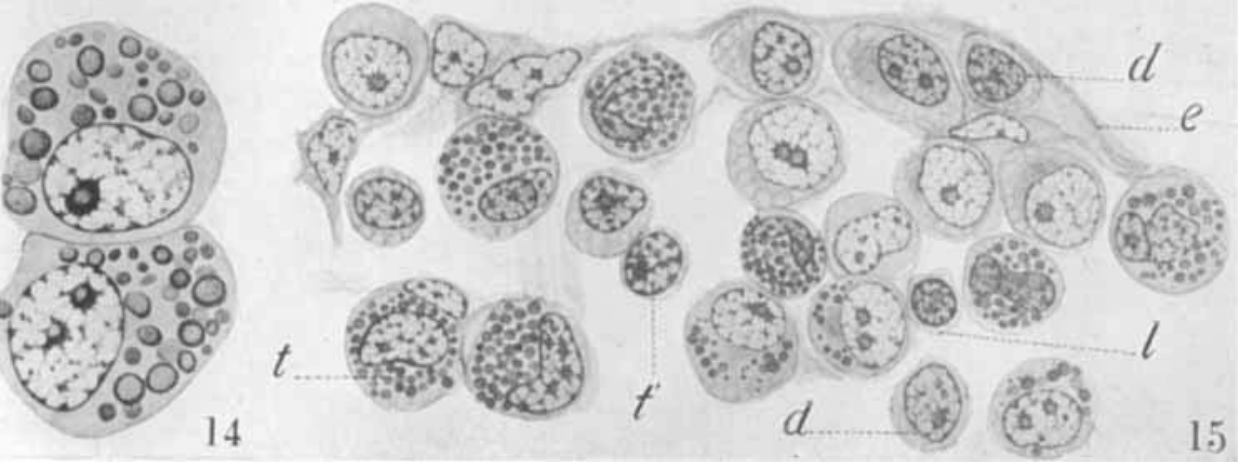


\section{PLATE 3}

\section{EXPLANATION OF FIGURES}

16 and 17 Gramulocytoblasts with creseent-shaped nuclei, representing the stage which precedes to the granulocytes represented in figures 7, 15, and 18 .

18 Myeloid metaplasis in the connestive tissue surrounding an egg-follicle in a pullet. $g$, degencrated granulocytos. Sections of a vein and an artery $(b)$ are seen in the figurc. Slide by Dr. H. D. Goodale. IIemat. eos.

19 Phagocytic cell found in a granulopoietic focus of the testis of the eighteenth-day embryo. The cytoplasm shows a faint network, but lacks a conspieuous sphere and centrosomes. Hem. eosin.

20 and 21 Phagocytic cells with engulfed granulocytoblasts in their cytoplasm; the coll in figure 20 is binucleate. Same material as in preceding figure.

22 Lymphoid metaplasis in the connective tissue of the regenerating testis of a mature Campine cock. Hem. eos.

23 to 28 Stages in the transformation of a small lymphonyte (first coll to the left in figure 23) into wandering cells. Figures 27 and 28 represent the large wandering cells thus produced, described by several authors under the names of Leydig cells and interstitial cells. Testis of a mature hen-feathered Campine cock, over one year old. Hem. eos.

29 Small lymphocyte with minute acidophile granules in the eytoplasm. From the mycloid metaplasis drawn in figure 18. 
JOSÉ $\mathrm{F}$. NONIDEZ

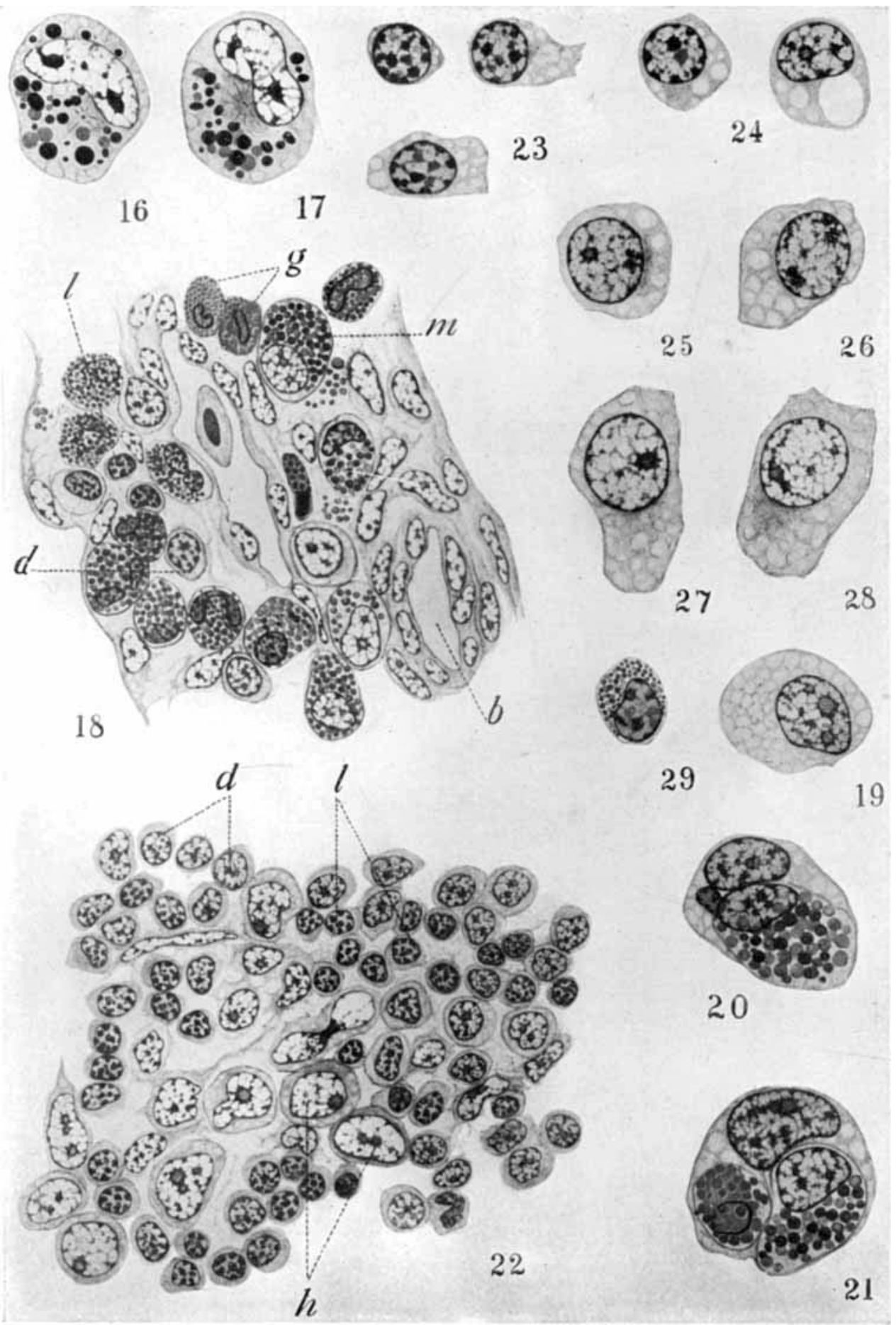

